\title{
Focus on Phytochemical Screening, Chemical Constituents, Pharmacological Effects and Medical Uses of Gummi myrrha
}

\author{
Khaled Mohamed Mohamed Koriem 1,*[D \\ 1 Department of Medical Physiology, Medical Research Division, National Research Centre, 33 El-Buhouth Street, Dokki, \\ Cairo, 12622, Egypt \\ * Correspondence: kkoriem@yahoo.com;
}

Scopus Author ID 24477156100

Received: 8.07.2021; Revised: 15.08.2021; Accepted: 20.08.2021; Published: 19.10.2021

\begin{abstract}
Gummi myrrha is the air-dried gum resin taken from the branches and stems of Commiphora molmol Engler (Burseraceae). The other names include myrrh, myrrhe, myrrha. Commiphora species are shrubs with $3 \mathrm{~m}$ high. It has rounded tops, thick trunks, dark brown bark, and large, sharply pointed thorns on the stem. It has many asymmetrical stunted and spiny. The leaves are unequal and alternate. The flowers are small, yellow-red fascicled, and arranged in terminal panicles. Gummi myrrha contains resins (25-40\%), essential oil (3-8\%), and a water-soluble gum (30-60\%). The Gummi myrrha contains $20 \%$ proteins and $65 \%$ carbohydrates (galactose, $4-O$-methylglucuronic acid, and arabinose). The major constituents of the Gummi myrrha essential oil are furanosesquiterpenes, and the monoterpenes $\alpha-, \beta-$ and $\gamma$-bisabolene. Gummi myrrha is used for mild inflammations treatment. It is used to treat aphthous ulcers, pharyngitis, tonsillitis, common cold, and gingivitis. Gummi myrrha is used as an emmenagogue, expectorant, and antidote for toxins and to stop blood coagulation. It treats menopausal symptoms, arthritic pain, diarrhea, fatigue, headache, jaundice, and indigestion. The pharmacology activity of Gummi myrrha includes experimental pharmacology and clinical pharmacology. Experimental pharmacology includes cardio-protective, analgesic, antipyretic, anticoagulant, antidiabetic, antiinflammatory, cytoprotective, antimicrobial, and antileishmanial activities. Clinical pharmacology includes anti-obesity, antidiarrheal, and wound healing activities. The ointment of Gummi myrrha essential oil was non-irritating, non-sensitizing, and non-photo toxic to the human skin. The dose of myrrh tincture $=1: 5 \mathrm{~g} / \mathrm{ml}$, Gummi myrrha tincture applied to the affected area 2 or 3 times/ day; Gummi myrrha mouth solution= 5-10 drops of the tincture in a glass of water.
\end{abstract}

Keywords: Gummi myrrha; Commiphora molmol; pharmacology; medicine; dose.

(c) 2021 by the authors. This article is an open-access article distributed under the terms and conditions of the Creative Commons Attribution (CC BY) license (https://creativecommons.org/licenses/by/4.0/).

\section{Introduction}

Gummi myrrha is the air-dried gum resin taken from the branches and stems of Commiphora molmol Engler (Burseraceae). Other names include myrrh, myrrhe, myrrha, Abyssinian myrrh, bal, barakande, bisabol myrrh, bola, guban myrrh, habaq-hagar-ad, heerbol, heerabol myrrh, mbebe, moyao, morr, myrr, Myrrhenbaum, molmol, turari, Somali myrrh [1 8]. Many Commiphora species are cultivated in tropical areas of Africa. Commiphora molmol occurs in Somalia, and it is cultivated in the Arabian Peninsula, North Africa, India, Ethiopia, Kenya, and Tanzania [1, 2, 7]. Commiphora species are shrubs with $3 \mathrm{~m}$ high. It has rounded tops, thick trunks, dark brown bark, and large, sharply pointed thorns on the stem. It has many https://biointerfaceresearch.com/ 
asymmetrical stunted and spiny. The leaves are unequal and alternate. The flowers are small, yellow-red fascicled, and arranged in terminal panicles. The calyx is tubular, and teeth while the petals are found inserted on the edge of the disk. The stamens have 8-10 on disk alternately long and dilated below. The fruits are oval drupes ( $0.3 \mathrm{~cm}$ long). Gummi myrrha is taken from the schizogenous resin duct when stems are damaged or incised [1, 2, 6, 8]. Commiphora leptophloeos possesses polyphenols such as rutin, vitexin, and quercetin diglycosides. Commiphora leptophloeos has an important in-vitro and in-vivo antioxidant effect [9]. Commiphora myrrha water extract resin is used against many diseases in Saudi Arabian patients, such as many diseases related to abnormal cytochrome P450 expression where it modulates cytochrome P450-2C8, cytochrome P450-2C9, cytochrome P450-2C19, and cytochrome P450-3A4 gene expression [10]. Guggulipid is an ethyl acetate extract of resin known as guggul from Commiphora wightii or Commiphora mukul. It is used to treat arthritis, inflammation, obesity, cardiac protection, antiulcer, anti-epileptic, and disorders of lipid metabolism [11]. Since ancient times, Commiphora myrrha has been used in traditional medicines against many health problems, including bone disorders. Commiphora myrrha has anti-inflammatory activities by inhibiting the secretion of nitric oxide and suppressing the cyclooxygenase- 2 , interleukin- 6 , interleukin- $1 \beta$, and inducible nitric oxide synthase expression [12].

\section{Chemical constituents of Gummi myrrha}

Gummi myrrha contains $6 \%$ essential oil [3]. The high-performance liquid chromatography revealed the appearance of furanosesquiterpenes constituent $[13,14]$. The phytochemical analyses of Commiphora leptophloeos leaf extract showed 6 flavonoids identified as orientin, isoorientin, vitexin and isovitexin, quercitrin, and isoquercitrin [15]. Commiphora wightii contains guggulsterones $\mathrm{E}$ and $\mathrm{Z}$ constituents which are responsible for plant pharmacological actions [16]. Commiphorane K, Commiphoranes L-N, sesquiterpenoids, commiphorane $\mathrm{O}$, and sesquiterpenoid were isolated from Commiphora Resina. Commiphoranes L suppresses lipopolysaccharide-stimulated production of tumor necrosis factor- $\alpha$ in a dose-dependent manner [17]. 2 new compounds (Sesquiterpene 1 and Sesquiterpene 2) were isolated from myrrh by chromatography analysis [18]. Arabic Commiphora myrrh resin contains 2 furano-sesquiterpenoids (2-methoxyfuranodiene and 2acetoxyfuranodiene) [19].

\section{Major chemical constituents of Gummi myrrha}

Gummi myrrha contains: resins (25-40\%), essential oil (3-8\%) and a water-soluble gum (30-60\%) [1, 20]. The Gummi myrrha contains $20 \%$ proteins and $65 \%$ carbohydrates (galactose, 4-O-methylglucuronic acid, and arabinose). The major constituents of the Gummi myrrha essential oil are furanosesquiterpenes [8] and the monoterpenes $\alpha$-, $\beta$ - and $\gamma$-bisabolene. A 2 new arabinofuranosidetridecanol (1,2-tridecanediol-1- $O$ - $\alpha$-L-5'-acetylarabinofuranoside and 1,2-tridecanediol-1- $O$ - $\alpha$-L-arabinofuranoside) together with 1,2-tridecanediol were isolated from Commiphora merkeri [21]. Commiphoins A-C (3 new cadinane-type sesquiterpenes) were isolated from the Commiphora myrrha, and they all had significant antiAlzheimer's disease activities [22]. 


\section{Gummi myrrha medicinal uses}

Gummi myrrha is found in 2 forms (an ointment and oral uses). As an ointment, it is used for mild inflammations treatment. As an oral use, it is used to treat aphthous ulcers, pharyngitis, tonsillitis, common cold, and gingivitis [3, 23-25]. Commiphora myrrha essential oils possess a nematicidal effect [26]. Commiphora myrrha and its resin (myrrh) treat many inflammatory and metabolic disorders. Therefore Gummi myrrha controls osteoporosis in postmenopausal women [27]. Commiphora molmol is used in the treatment of early/mild common flu and especially in COVID-19 treatment. Commiphora molmol improves general patient well-being and pushes the human towards the therapeutic approaches [28]. Commiphora molmol showed higher cure rates than Praziquantel (standard treatment for immunocompetent and immunocompromised). It reached $100 \%$ good improvement of histopathological variations in the intestine and liver [29]. Commiphora mukul has proandrogenic activity and performs an important effect on sperm parameters in diabetic rats, where it increases the total sperm count and decreases the proportion of sperm with abnormal morphology [30].

\section{Gummi myrrha in traditional medicine}

Gummi myrrha is used as an emmenagogue, expectorant, and antidote for toxins and to stop blood coagulation. It is treated menopausal symptoms, arthritic pain, diarrhea, fatigue, headache, jaundice, and indigestion. It is used for the treatment of burns and hemorrhoids in the form of an ointment $[7,8,31,32]$. Commiphora myrrha has anti-viral, antipyretic, blood purifier, cardioprotective and expectorant activities [33]. Commiphora mukul is applied for the treatment of osteoarthritis in traditional Persian medicine. This disease is known to be the leading cause of pain and disability in the elderly [34]. Commiphora mukul ameliorates inflammatory factors (interleukin- $1 \beta$ and tumor necrosis factor- $\alpha$ ) and antioxidative factors (catalase, glutathione, superoxide dismutase, malondialdehyde and nitrite). Also, Commiphora mukul prevented brain apoptosis by the inhibition of brain caspase-3 and Bax therefore, Commiphora mukul is useful to treat multiple sclerosis-related symptoms [35].

\section{Pharmacology of Gummi myrrha}

\subsection{Experimental pharmacology.}

\subsubsection{Cardioprotective activity.}

Commiphora molmol has a cardio-protective effect in the myocardial Infarction animal model by improving oxidative stress and myocytes. Commiphora molmol abolishes apoptotic and inflammatory activities in the myocardial Infarction animal model [36].

\subsubsection{Analgesic and antipyretic activities.}

The water suspension of Gummi myrrha had analgesic effects in mice by the hot-plate assay [37]. The intake of $50 \mathrm{mg} / \mathrm{kg}$ of a sesquiterpene, furanoeudesma-1,3-diene (taken from Gummi myrrha resin also had analgesic effects in mice as measured by the acetic acid writhing test [37]. The analgesic effect of Prunus armeniaca is similar in its effect to Cupressus sempervirens in its effect [38]. The intake of $400 \mathrm{mg} / \mathrm{kg}$ of ethanol extract of the resin declined 
writhing induced by acetic acid in mice by $25 \%$ [39]. The intake of $500 \mathrm{mg} / \mathrm{kg}$ of petroleum ether extract or ethanol extract of Gummi myrrha resin declined yeast-induced pyrexia in mice $[40,41]$.

\subsubsection{Anticoagulant activity.}

The intake of $100 \mathrm{mg} / \mathrm{kg}$ bw of ethyl acetate extract of Gummi myrrha resin stopped platelet aggregation in mice. The water extract of Gummi myrrha resin was not active [38]. The intake of $100 \mathrm{mg} / \mathrm{kg}$ of ethyl acetate extract of Gummi myrrha resin had antithrombotic activity in mice [42]. Commiphora mukul declined anal irritation, bleeding, pain, and swelling sense; therefore, Commiphora mukul improved clinical signs and symptoms in patients with hemorrhoids [43].

\subsubsection{Antidiabetic activity.}

The intake of $10 \mathrm{ml} / \mathrm{kg}$ of water extract of Gummi myrrha resin/ day for 7 days declined blood glucose levels in diabetic rats [44]. The intake of $150-175 \mathrm{mg} / \mathrm{kg}$ of 2 furanosesquiterpenes (taken from Gummi myrrha resin) declined blood glucose levels in obese diabetic mice [45]. Commiphora myrrha resin $(0.5-10 \mathrm{mg} / \mathrm{ml})$ induced a concentrationdependent increase in insulin secretion where stimulation of insulin secretion in a concentration-dependent manner occurred after incubation of mice islets to Commiphora myrrha $(0.1-10 \mathrm{mg} / \mathrm{ml})$. Commiphora myrrha $(2 \mathrm{mg} / \mathrm{ml})$ caused rapid and reversible increases in insulin secretion from both mouse and human islets; therefore, Commiphora myrrha resin solution has a direct stimulatory effect on $\beta$-cells of Langerhans [46].

\subsubsection{Anti-inflammatory activity.}

The intake of $400 \mathrm{mg} / \mathrm{kg}$ of water extract of Gummi myrrha resin to rats stopped carrageenan-induced footpad edema by $59 \%$ [45]. The intake of $400 \mathrm{mg} / \mathrm{kg}$ of petroleum ether extract of Gummi myrrha resin/ day for 18 days to rats with Freund's adjuvant-induced arthritis declined the inflammation progress [45]. The intake of $80 \mathrm{mg} / \mathrm{kg}$ of petroleum ether extract of Gummi myrrha resin stopped carrageenan-induced edema in rats [47]. The intake of 200-400 $\mathrm{mg} / \mathrm{kg}$ of ethanol extract of Gummi myrrha resin declined xylene-induced ear inflammation in mice by 50\% [48]. Commiphora leptophloeos declined the paw-edema and decreased myeloperoxidase effect at 200 and $400 \mathrm{mg} / \mathrm{kg}$ doses. Commiphora leptophloeos reduced the leukocytes migration, total protein concentration, myeloperoxidase, and malondialdehyde levels. Commiphora leptophloeos declined tumor necrosis factor- $\alpha$ level and increased interleukin-10 secretion [49]. Commiphora molmol exhibited an anti-inflammatory effect via the inhibition of the inflammatory mediator release. An intestinal barrier stabilizing effect was observed for myrrh from Commiphora molmol. Thus, Commiphora molmol is used in the treatment of an inflammatory bowel disease [50].

\subsubsection{Cytoprotective activity.}

The intake of $250 \mathrm{mg} / \mathrm{kg}$ of a water suspension of Gummi myrrha resin declined the formation of ulcers induced by ethanol, sodium chloride, and indomethacin in rats by increasing the secretion of gastric mucus [51]. Commiphora kua ameliorates transaminase enzymes, lactate dehydrogenase, alkaline phosphatase, and bilirubin, as well as, increases 
antioxidant activity such as superoxide dismutase, catalase, and glutathione and induces important improvement of liver tissues; therefore, it possesses hepatoprotective effect [52].

\subsubsection{Antimicrobial and antileishmanial activities.}

Commiphora molmol with fluconazole against Candidaalbicans showed the best synergistic antibacterial activity [53]. On the other hand, Commiphora wightii possesses an antileishmanial effect [54]. Commiphora molmol manufactures silver nanoparticles with antiparasitic effects such as the anti-leishmanial effect in in-vitro and in-vivo studies [55]. Commiphora leptophloeos has an antifungal and antibiofilm effect. It is safe for human erythrocytes. Also, B-type oligomeric procyanidins, which were isolated from Commiphora leptophloeos exhibited an antifungal effect against Candida strains [49]. The furanodienone and curzerene constituent of Commiphora myrrha affect viral replication by acting on different steps of the virus life cycle [56]. Myrrh oil from Commiphora molmol has antibacterial activity and causes no bacterial resistance to occur. This is an exceptional example of an antibiotic that kills non-growing bacteria [57]. Myrrh essential oil has antibacterial and cytotoxic agents (on human liver cancer, human breast cancer, and colon cancer cell lines [58]. Commiphora myrrha showed antibacterial activity; therefore, it treated mixed cutaneous infections [59].

\subsection{Clinical pharmacology.}

\subsubsection{Anti-obesity activity.}

Three months of treatment with Commiphora mukul declined serum cholesterol by $1.9 \%$ in the placebo and $3.3 \%$ in the intervention groups. Serum low-density lipoproteins declined by $4.9 \%$ and $4.8 \%$ in the placebo and intervention groups, respectively [60]. The increased fatty acid oxidation and lipolysis of Commiphora myrrha play an important role in decreasing lipids [61] Commiphora mukul treatment for 12 weeks declined low-density lipoprotein and cholesterol values by $18.78 \mathrm{mg} / \mathrm{dL}$ and $16.78 \mathrm{mg} / \mathrm{dL}$, respectively, without any side effects [62]. Guggulsterone, the constituent in Commiphora wighti and Commiphora mukul, possess good cholesterol-lowering, appetite-regulating, and immunomodulatory effect [63]. The cholesterol-lowering and immunomodulatory effects of Commiphora myrrha play an important role in protecting from infectious diseases [64]. Commiphoranoids A-E (5 new sesquiterpenoids, dinorditerpenoids, and heterodimers with carbon skeletons) were isolated from Resina Commiphora. These metabolites possess lipid regulatory activities [65]. Commiphora myrrha ameliorated a high-fat diet that caused higher body glucose, more body gain, high body fat, and ketone. These metabolites restored higher liver oxidative production, liver histopathology, and higher protein expression [66].

\subsubsection{Antidiarrheal activity.}

Commiphora leptophloeos leaf ethanol extract has an antidiarrheal effect due to inhibiting intestinal motility and antispasmodic effect through the antagonism of muscarinic receptors [67]. 
6.2.3. Wound healing activity.

Myrrh mouthwash has an improvement activity on wound healing during the early period after tooth extraction. Thus, Myrrh mouthwash improves postoperative surgical-site edema, tenderness, and socket size [68]. An improvement in the episiotomy wound healing was significantly greater in patients receiving Commiphora myrrha than those receiving the frankincense or betadine on 2nd and 7th postpartum days in primiparous women [69].

\section{Toxicology of Gummi myrrha}

The oral intake of ethanol extract of Gummi myrrha resin in rats $(1000 \mathrm{mg} / \mathrm{kg})$, intramuscular injection $(500 \mathrm{mg} / \mathrm{kg})$, or intraperitoneal injection $(250 \mathrm{mg} / \mathrm{kg})$ daily for 2 weeks induced huddling, ruffled hair, depression, jaundice, hepato-nephropathy, hemorrhagic myositis and patchy peritonitis at the injection site. Also, there was an increase in serum alanine phosphatase, alanine aminotransferase, bilirubin, cholesterol, creatinine levels, and decreased total protein and albumin levels. With the decrease of the above-mentioned doses to their halves, the adverse effects were declined [70]. The oral lethal dose of the essential oil is 1.65 $\mathrm{g} / \mathrm{kg}$ in rats [71]. There were no deaths reported in mice after intra-gastric injection of $3 \mathrm{~g} / \mathrm{kg}$ of ethanol extract of Gummi myrrha resin [37].

Commiphora leptophloeos has no cytotoxicity, and acute toxicity did not result in any sign of toxicity and mortality or significant changes on the biochemical parameters [49]. The intragastric injection of $500 \mathrm{mg} / \mathrm{kg}$ of petroleum ether extract of Gummi myrrha resin declined carrageenan-induced edema and cotton pellet-induced granuloma in rats [23]. The intra-gastric intake of $-5 \mathrm{~g} / \mathrm{kg}$ of the resin/ day to Nubian goat kids caused grinding of teeth, salivation, soft feces, in-appetence, jaundice, dyspnoea, ataxia, and recumbency. There was an increase in serum alanine phosphatase activity and bilirubin, cholesterol, triglycerides, and creatinine levels while decreasing total protein and albumin levels. The oral dose of $0.25 \mathrm{~g} / \mathrm{kg} /$ day was not toxic [72].

The oral intake of Gummi myrrha resin for 24 hours (acute) and 90 days (chronic) toxicity studies in mice at doses of $0.5 \mathrm{~g} / \mathrm{kg}, 1 \mathrm{~g} / \mathrm{kg}$, or $3 \mathrm{~g} / \mathrm{kg}$, and $100 \mathrm{mg} / \mathrm{kg} /$ day, respectively showed no significant increase in mortality in an acute or chronic study. In the chronic study, there was an increase in body weight and increases in the weight of the testes, cauda epididymides, and seminal vesicles in treated animals compared with controls. Treated animals also showed an increase in red blood cells and hemoglobin levels. No spermato-toxic effects were observed in treated animals [73].

\section{Pharmacokinetic and pharmacodynamics of Gummi myrrha}

Commiphora mukul increased the bioavailability of Rosuvastatin calcium (a potent synthetic inhibitor used to treat dyslipidemia) in both single-dose and multiple-dose. It reduced the absorption rate of Rosuvastatin calcium but showed an increase in the maximum serum concentration of Rosuvastatin calcium. Commiphora mukul decreased the rate of absorption of Rosuvastatin calcium in the intestinal lumen. The hypolipidemic activity of Rosuvastatin calcium was augmented by Commiphora mukul extract in hyperlipidemic rats [74]. 


\section{Adverse reactions of Gummi myrrha}

The ointment of Gummi myrrha essential oil was non-irritating, non-sensitizing, and non-phototoxic to the human skin [47], although, in other studies, the ointment of the resin to the human skin caused contact dermatitis [75-77].

\section{Contraindications of Gummi myrrha}

Gummi myrrha is used as an emmenagogue, although its safety during pregnancy has not been established. Therefore, Gummi myrrha should be used during pregnancy under a professional doctor [78].

\section{Warnings of Gummi myrrha}

The Gummi myrrha resin tincture may cause a transient burning sensation and irritation of the palate [3].

\section{Precautions of Gummi myrrha}

\subsection{Drug interactions.}

There is no drug interaction that has been reported, but oral intake of Gummi myrrha may interfere with antidiabetic drugs due to the resin declining the blood glucose level. Patients taking anticoagulant drugs should check their healthcare provider before use of the resin.

\subsection{Carcinogenesis, mutagenesis, impairment of fertility.}

Water extract of Gummi myrrha resin (40 mg/plate) without any mutagenic activity in Salmonella/microsome test using Salmonella typhimurium strains [79]. The intra-peritoneal injection of water extract of Gummi myrrha resin (10-40 times the normal therapeutic dose) did not have mutagenic effects [80]. The water extract of the resin (40 mg/plate) inhibited aflatoxin B1-induced mutagenesis in Salmonella typhimurium strains [80]. Commiphora mukul has been shown to have an antitumor effect in non-small cell lung cancer [81]. The antitumor effect of Gummi myrrha plays an important role in colon cancer protection [82]. Commiphora wightii has anti-cancer and anti-metastatic effects in both murine and human breast cancer cell lines. Thus, Commiphora wightii treats breast cancer growth and metastasis [83]. The intragastric injection of $125-500 \mathrm{mg} / \mathrm{kg}$ of Gummi myrrha resin did not have clastogenic effects but was cytotoxic in normal mice. In the mice bearing tumors, the resin had antitumor activity and was reported to be as effective as the antitumor agent cyclophosphamide [84].

\subsection{Pregnancy: non-teratogenic effects.}

Gummi myrrha should be used during pregnancy under a professional doctor [77].

\subsection{Nursing mothers.}

The Gummi myrrha should not be used by nursing mothers without consulting a healthcare practitioner. 
11.5. Paediatric use.

The Gummi myrrha should not be administered to children without consulting a healthcare practitioner.

\subsection{Other precautions.}

There is no information on Gummi myrrha general precautions or precautions concerning drug and laboratory test interactions; or teratogenic effects in pregnancy.

\section{Dose of Gummi myrrha}

There are many forms of Gummi myrrha such as; capsules, powdered resin, myrrh tincture, and ointment form for topical use [24]. Gummi myrrha should be stored in a tightly sealed container away from heat and light. Myrrh tincture $(1: 5 \mathrm{~g} / \mathrm{ml}, 90 \%$ ethanol $)$, undiluted tincture applied to the affected area 2 or 3 times/ day; mouth rinse solution (5-10 drops of the tincture) in a glass of water [24]; mouthwash solution (30-60 drops of the tincture) in a glass of warm water [23]; Gummi myrrha ointment applied to the affected areas on the gums or the mucous membranes of the mouth with a brush or cotton swab, 2 or 3 times/ day [23]; Gummi myrrha dental powder (10\% powdered gum resin) [24].

\section{Conclusions}

Gummi myrrha is the air-dried gum resin taken from the branches and stems of Commiphora molmol Engler (Burseraceae). The other names include myrrh, myrrhe, myrrha. Gummi myrrha contains resins (25-40\%), essential oil (3-8\%), and a water-soluble gum (30$60 \%$ ). Gummi myrrha is used to treat aphthous ulcers, pharyngitis, tonsillitis, common cold, and gingivitis. It treats menopausal symptoms, arthritic pain, diarrhea, fatigue, headache, jaundice, and indigestion. The pharmacology activity of Gummi myrrha includes experimental and clinical pharmacology. Experimental pharmacology includes cardio-protective, analgesic, antipyretic, anticoagulant, antidiabetic, anti-inflammatory, cytoprotective, antimicrobial, and antileishmanial activities. Clinical pharmacology includes anti-obesity, antidiarrheal, and wound healing activities. The ointment of Gummi myrrha essential oil was non-irritating, nonsensitizing, and non-phototoxic to the human skin. The dose of myrrh tincture $=1: 5 \mathrm{~g} / \mathrm{ml}$, Gummi myrrha tincture applied to the affected area 2 or 3 times/ day.

\section{Funding}

This review received no external funding.

\section{Acknowledgments}

This research has no acknowledgment.

\section{Conflict of interest}

The author declares no conflict of interest. 


\section{References}

1. Inter African Committee on Medicinal Plants and African Traditional Medicine. African pharmacopoeia. Organization of African Unity, Scientific, Technical and Research Commission 1985, Vol. 1.

2. Central Council for Research in Unani Medicine. Standardization of single drugs of Unani medicine- part II. New Delhi, Ministry of Health and Family Welfare 1992.

3. Willoughby, M.J.; Mills, S.; British Herbal Medicine Association. Scientific Committee. British herbal pharmacopoeia. Exeter, British Herbal Medicine Association 1996.

4. European pharmacopoeia, Suppl. 2001, 3rd ed. 2021,Strasbourg, Council of Europe 2000.

5. Hansel, R.; Keller, K.; Rimpler, H.; Schneider, G.; eds. Hagers Handbuch der pharmazeutischen Praxis. Bd 4,Drogen $A-D$, 5th ed. [Hager's handbook of pharmaceutical practice. Vol. 4, Drugs A-D, 5th ed.] Berlin, Springer, 1992.

6. Youngken, H.W. Textbook of pharmacognosy. The Blakiston Company 1950, 6th ed. Philadelphia, PA, Blakiston.

7. Iwu, M.M. Handbook of African medicinal plants. Boca Raton, FL, CRC Press 1993.

8. Bisset, N.G. Herbal drugs and phytopharmaceuticals. Boca Raton, FL, CRC Press 1994.

9. Cordeiro, M.L.D.S.; Ribeiro, A.R.C.; de Melo, L.F.M.; da Silva, L.F.; Fidelis, G.P.; Silva, L.M.P.; Caland, R.B.O.; Cadavid, C.O.M.; Aragão, C.F.S.; Zucolotto, S.M.; Oliveira, R.P.; Dos Santos, D.Y.A.C.; Rocha, H.A.O.; Scortecci, K.C. Antioxidant activities of Commiphora leptophloeos (Mart.) J. B. Gillett) (Burseraceae) leaf extracts using in vitro and in vivo assays. Oxid Med Cell Longev 2021, 2021, 3043720, http://doi.org/10.1155/2021/3043720.

10. Alehaideb, Z.; Alatar, G.; Nehdi, A.; Albaz, A.; Al-Eidi, H.; Almutairi, M.; Hawsa, E.; Alshuail, N.; MatouNasri, S. Commiphora myrrha (Nees) Engl. resin extracts induce phase-I cytochrome P450 2C8, 2C9, 2C19, and 3A4 isoenzyme expressions in human hepatocellular carcinoma (HepG2) cells. Saudi Pharm J 2021, 29, 361-368, http://doi.org/10.1016/j.jsps.2021.03.002.

11. Ahmad, M.A.; Mujeeb, M.; Akhtar, M.; Khushtar, M.; Arif, M.; Haque, M.R. Guggulipid: A Promising multipurpose herbal medicinal agent. Drug Res (Stuttg) 2020, 70, 123-130, http://doi.org/10.1055/a-1115-4669.

12. Lee, D.; Ju, M.K.; Kim, H. Commiphora extract mixture ameliorates monosodium iodoacetate-induced osteoarthritis. Nutrients 2020, 12, 1477, http://doi.org/10.3390/nu12051477.

13. Wagner, H.; Bladt, S. Plant drug analysis - a thin-layer chromatography atlas, 2nd ed. Berlin, Springer 1996.

14. Maradufu, A.; Warthen, J.D. Jr. Furanosesquiterpenoids from Commiphora myrrh oil. Plant Science 1988, 57, 181-184, https://doi.org/10.1016/0168-9452(88)90085-4.

15. Dantas-Medeiros, R.; Furtado, A.A.; Zanatta, A.C.; Torres-Rêgo, M.; Guimarães Lourenço, E.M.; Ferreira Alves, J.S.; Galinari, É.; Alexandre de Oliveira Rocha, H.; Bernardo Guerra, G.C.; Vilegas, W.; Antônio de Sousa Araújo, T.; de Freitas Fernandes-Pedrosa, M.; Zucolotto, S.M. Mass spectrometry characterization of Commiphora leptophloeos leaf extract and preclinical evaluation of toxicity and anti-inflammatory potential effect. J Ethnopharmacol 2021, 264, 113229, http://doi.org/10.1016/j.jep.2020.113229.

16. Menon, I.M.; Eapen, J.; Deepa, M.S. Comparative HPTLC fingerprinting profile and GC-MS analysis of raw and purified Guggulu (Commiphora wightii. Arn. Bhand) by Ayurvedic purification method. J Complement Integr Med 2021, http://doi.org/10.1515/jcim-2020-0347.

17. Yang, X.; Wang, D.; Yan, Y.; Jiao, Y.; Cheng, Y.X.; Wang, F. Commiphoranes K-O, new terpenoids from Resina Commiphora and their anti-inflammatory activities. Chem Biodivers 2021, 18, e2100265, http://doi.org/10.1002/cbdv.202100265.

18. Kuck, K.; Jürgenliemk, G.; Lipowicz, B.; Heilmann, J. Sesquiterpenes from Myrrh and their ICAM-1 inhibitory activity in vitro. Molecules 2020, 26, 42, http://doi.org/10.3390/molecules26010042.

19. Alqahtani, A.S.; Nasr, F.A.; Noman, O.M.; Farooq, M.; Alhawassi, T.; Qamar, W.; El-Gamal, A. Cytotoxic evaluation and anti-angiogenic effects of two furano-sesquiterpenoids from Commiphora myrrh resin. Molecules 2020, 25, 1318, http://doi.org/10.3390/molecules25061318.

20. Newall, C.A.; Anderson, L.A.; Phillipson, J.D. Herbal medicines, a guide for healthcare professionals. London, The Pharmaceutical Press 1996.

21. Samwel, B.; Innocent, E.; Machumi, F.; Kisinza, W.N.; Heydenreich, M. Two mosquito larvicidal arabinofuranosidetridecanol from Commiphora merkeri exudate. Nat Prod Res 2021, 1-9, http://doi.org/10.1080/14786419.2021.1931866. 
22. Yu, Y.F.; Liu, Y.H.; Chen, X.H.; Zhi, D.J.; Qi, F.M.; Zhang, Z.P.; Li, Y.Q.; Zhang, Z.X.; Fei, D.Q. Cadinanetype sesquiterpenes from the resinous exudates of Commiphora myrrha and their anti-Alzheimer's disease bioactivities. Fitoterapia 2020, 142, 104536, http://doi.org/10.1016/j.fitote.2020.104536.

23. Braun, R.; Zapf, T. Standardzulassungen für Fertigarzneimittel - Text und Kommentar. [Standard licensing of finished drugs - text and commentary.] Stuttgart, Deutscher Apotheker Verlag 1997.

24. Blumenthal, M.; Werner, R.; Busse, J.; Klein, R.; Rister, T.; Hall, C.; Riggins; Gruenwald, J. Alicia Goldberg eds. The complete German Commission E monographs. Austin, TX, American Botanical Council 1998.

25. Bradley, P.R. ed. British herbal compendium. Vol. 1. Bournemouth, British Herbal Medicine Association, 1992.

26. Kundu, A.; Dutta, A.; Mandal, A.; Negi, L.; Malik, M.; Puramchatwad, R.; Antil, J.; Singh, A.; Rao, U.; Saha, S.; Kumar, R.; Patanjali, N.; Manna, S.; Kumar, A.; Dash, S.; Singh, P.K. A comprehensive in vitro and in silico analysis of nematicidal action of essential oils. Front Plant Sci 2021, 8, 11:614143, http://doi.org/10.3389/fpls.2020.614143.

27. Hwang, Y.H.; Lee, A.; Kim, T.; Jang, S.A.; Ha, H. Anti-osteoporotic effects of Commiphora Myrrha and its poly-saccharide via osteoclastogenesis inhibition. Plants (Basel) 2021, 10, 945, http://doi.org/10.3390/plants10050945.

28. Silveira, D.; Prieto-Garcia, J.M.; Boylan, F.; Estrada, O.; Fonseca-Bazzo, Y.M.; Jamal, C.M.; Magalhães, P.O.; Pereira, E.O.; Tomczyk, M.; Heinrich, M. COVID-19: Is There evidence for the use of herbal medicines as adjuvant symptomatic therapy? Front Pharmacol 2020, 11, 581840, http://doi.org/10.3389/fphar.2020.581840.

29. Bayoumy, A.M.S.; Hamza, H.T.; Alotabi, M.A. Histopathological and biochemical studies on immunocompetent and immunocompromised Hymenolepis nana infected mice treated with Commiphora molmol (Mirazid). J Parasit Dis 2020, 44, 837-849, http://doi.org/10.1007/s12639-020-01263-z.

30. Rezaei, A.A.; Salehi, I.; Karimi, S.A.; Rahnama, M. The effects of Commiphora mukul extract on spermatogenesis and testosterone levels in male diabetic rats. Clin Exp Reprod Med 2020, 47, 34-41, http://doi.org/10.5653/cerm.2019.03251.

31. Nadkarni, K.M. Indian materia medica. Bombay, Popular Prakashan 1976.

32. Frawley, D.; Lad, V. The yoga of herbs: an Ayurvedic guide to herbal medicine. Twin Lakes, WI, Lotus Press 1986.

33. Fatima, S.; Haider, N.; Alam, M.A.; Gani, M.A.; Ahmad, R.; Taha. M. Herbal approach for the management of C0VID-19: an overview. Drug Metab Pers Ther 2020, http://doi.org/10.1515/dmdi-2020-0150.

34. Karami, S.; Shamshiri, S.; Abdollahi, M.; Rahimi, R. An Evidence-based review of medicinal plants used in traditional persian medicine for treatment of osteoarthritis. Curr Drug Discov Technol 2021, 18, 244-271, http://doi.org/10.2174/1570163817666200316105658.

35. Kumar, N.; Sharma, N.; Khera, R.; Gupta, R.; Mehan, S. Guggulsterone ameliorates ethidium bromideinduced experimental model of multiple sclerosis via restoration of behavioral, molecular, neurochemical and morphological alterations in rat brain. Metab Brain Dis 2021, 36, 911-925, http://doi.org/10.1007/s11011021-00691-X.

36. Younis, N.S.; Mohamed, M.E. Protective effects of myrrh essential oil on isoproterenol-induced myocardial infarction in rats through antioxidant, anti-inflammatory, Nrf2/HO-1 and apoptotic pathways. $J$ Ethnopharmacol 2021, 270, 113793, http://doi.org/10.1016/j.jep.2021.113793.

37. Dolara, P.; Moneti, G.; Pieraccini, G.; Romanelli, N. Characterization of the action of central opioid receptors of furaneudesma-1,3-diene, a sesquiterpene extracted from myrrh. Phytother Res 1996, 10, S81-S83.

38. Koriem, K.M.M.; Gad, I.B.; Nasiry, Z.K. Protective effect of Cupressus sempervirens extract against indomethacin-induced gastric ulcer in rats. Interdiscip Toxicol 2015, 8, 25-34, https://doi.org/10.1515/intox2015-0006.

39. Kosuge, T.; Ishida, H.; Yamazaki, H.; Ishii, M. [Studies on active substances in the herbs used for oketsu, blood coagulation, in Chinese medicine. I. On anticoagulative activities of the herbs for oketsu.] Yakugaku Zasshi 1984, 104, 1050-1053, http://doi.org/10.1248/yakushi1947.104.10_1050.

40. Tariq, M.; Ageel, A.M.; Al-Yahya, M.A.; Mossa, J.S.; Al-Said, M.S.; Parmar, N.S. Anti-inflammatory activity of Commiphora molmol. Agents Actions 1986, 17, 381-382, http://doi.org/10.1007/BF01982655.

41. Mohsin, A.; Shah, A.H.; Al-Yahya, M.A.; Tariq, M.; Tanira, M.O.M.; Ageel, A.M. Analgesic, antipyretic activity and phytochemical screening of some plants used in traditional Arab system of medicine. Fitoterapia 1989, 60, 174-177. 
42. Olajide, O.A. Investigation of the effects of selected medicinal plants on experimental thrombosis. Phytother Res 1999, 13, 231-232, http://doi.org/10.1002/(SICI)1099-1573(199905)13:3<231::AID-PTR414>3.0.CO;22.

43. Mehdi, Z.; Fatemeh, P.; Roja, R.; Fatemeh, H.; Hamid Reza, S.; Jafar, N.; Mohammad Hosein, F. Efficacy and safety of Hemoheal cream in patients with hemorrhoids: a randomized double-blind placebo controlled clinical trial. J Tradit Chin Med 2021, 41, 301-307, http://eprints.kums.ac.ir/10783/\#: :text=http\%3A//eprints.kums.ac.ir/id/eprint/10783.

44. Al-Awadi, F.M.; Gumaa, K.A. Studies on the activity of individual plants of an antidiabetic plant mixture. Acta Diabetol Lat 1987, 24, 37-41, http://doi.org/10.1007/BF02732051.

45. Ubillas, R.P.; Mendez, C.D.; Jolad, S.D.; Luo, J.; King, S.R.; Carlson, T.J.; Fort, D.M. Antihyperglycemic furanosesquiterpenes from Commiphora myrrha. Planta Medica 1999, 65, 778-779, http://doi.org/10.1055/s2006-960870.

46. Al-Romaiyan, A.; Huang, G.C.; Jones, P.; Persaud, S. Commiphora myrrha stimulates insulin secretion from mouse and human islets of Langerhans. $J$ Ethnopharmacol 2021, 264, 113075, http://doi.org/10.1016/j.jep.2020.113075.

47. Mossa, J.S. Studies on anti-inflammatory activity of Balsamodendron myrrhanees. In Advances in Chinese medicinal material research: an international symposium held in Meridien Hotel, Hong Kong, 1984.

48. Atta, A.H.; Alkofahi, A. Anti-nociceptive and anti-inflammatory effects of some Jordanian medicinal plant extracts. J Ethnopharmacol 1998, 60, 117-124, http://doi.org/10.1016/s0378-8741(97)00137-2.

49. Dantas-Medeiros, R.; Zanatta, A.C.; de Souza, L.B.F.C.; Fernandes, J.M.; Amorim-Carmo, B.; Torres-Rêgo, M.; Fernandes-Pedrosa, M.F.; Vilegas, W.; Araújo, T.A.S.; Michel, S.; Grougnet, R.; Chaves, G.M.; Zucolotto, S.M. Antifungal and antibiofilm activities of B-type oligomeric procyanidins from Commiphora leptophloeos used alone or in combination with fluconazole against Candida spp. Front Microbiol 2021, 12, 613155, http://doi.org/10.3389/fmicb.2021.613155.

50. Weber, L.; Kuck, K.; Jürgenliemk, G.; Heilmann, J.; Lipowicz, B.; Vissiennon, C. Anti-inflammatory and barrier-stabilising effects of Myrrh, coffee charcoal and chamomile flower extract in a co-culture cell model of the intestinal mucosa. Biomolecules 2020, 10, 1033, http://doi.org/10.3390/biom10071033.

51. Al-Harbi, M.M.; Qureshi, S.; Raza, M.; Ahmed, M.M.; Afzal, M.; Shah, A.H. Gastric antiulcer and cytoprotective effect of Commiphora molmol in rats. $J$ Ethnopharmacol 1997, 55, 141-150, http://doi.org/10.1016/s0378-8741(96)01488-2.

52. Ullah, H.; Khan, A.; Rehman, N.U.; Halim, S.A.; Khan, H.; Khan, I.; Csuk, R.; Al-Rawahi, A.; Al-Hatmi, S.; Al-Harrasi, A. Lophenol and lathosterol from resin of Commiphora kua possess hepatoprotective effects in vivo. J Ethnopharmacol 2020, 252, 112558, http://doi.org/10.1016/j.jep.2020.112558.

53. Arora, S.; Saquib, S.A.; Algarni, Y.A.; Kader, M.A.; Ahmad, I.; Alshahrani, M.Y.; Saluja, P.; Baba, S.M.; Abdulla, A.M.; Bavabeedu, S.S. Synergistic effect of plant extracts on endodontic pathogens isolated from teeth with root canal treatment failure: An in vitro study. Antibiotics (Basel) 2021, 10, 552, http://doi.org/10.3390/antibiotics10050552.

54. Routaray, C.B.; Bhor, R.; Bai, S.; Kadam, N.S.; Jagtap, S.; Doshi, P.J.; Sundar, S.; Sawant, S.; Kulkarni, M.J.; Pai, K. SWATH-MS based quantitative proteomics analysis to evaluate the antileishmanial effect of Commiphora wightii- Guggul and amphotericin B on a clinical isolate of Leishmania donovani. J Proteomics 2021, 232, 104017, http://doi.org/10.1016/j.jprot.2020.104017.

55. Awad, M.A.; Al Olayan, E.M.; Siddiqui, M.I.; Merghani, N.M.; Alsaif, S.S.A.; Aloufi, A.S. Antileishmanial effect of silver nanoparticles: Green synthesis, characterization, in vivo and in vitro assessment. Biomed Pharmacother 2021, 137, 111294, http://doi.org/10.1016/j.biopha.2021.111294.

56. Madia, V.N.; De Angelis, M.; De Vita, D.; Messore, A.; De Leo, A.; Ialongo, D.; Tudino, V.; Saccoliti, F.; De Chiara, G.; Garzoli, S.; Scipione, L.; Palamara, A.T.; Di Santo, R.; Nencioni, L.; Costi, R. Investigation of Commiphora myrrha (Nees) Engl. Oil and its main components for antiviral activity. Pharmaceuticals (Basel) 2021, 14, 243, https://doi.org/10.3390/ph14030243.

57. Bhattacharjee, M.K.; Alenezi, T. Antibiotic in myrrh from Commiphora molmol preferentially kills nongrowing bacteria. Future Sci OA 2020, 6, FSO458, http://doi.org/10.2144/fsoa-2019-0121.

58. Khalil, N.; Fikry, S.; Salama, O. Bactericidal activity of Myrrh extracts and two dosage forms against standard bacterial strains and multidrug-resistant clinical isolates with GC/MS profiling. AMB Express 2020, 10, 21, http://doi.org/10.1186/s13568-020-0958-3. 
59. Ebani, V.V.; Bertelloni, F.; Najar, B.; Nardoni, S.; Pistelli, L.; Mancianti, F. Antimicrobial activity of essential oils against Staphylococcus and Malassezia strains isolated from canine dermatitis. Microorganisms 2020, 8, 252, http://doi.org/10.3390/microorganisms8020252.

60. Donato, F.; Raffetti, E.; Toninelli, G.; Festa, A.; Scarcella, C.; Castellano, M. Guggulu and Triphala for the treatment of hypercholesterolaemia: A placebo-controlled, double-blind, randomised trial. Complement Med Res 2021, 28, 216-225, http://doi.org/10.1159/000510985.

61. Koriem, K.M.M. Antihyperlipidemic activity of the medicinal plants among Kadazan and Dusun communities in Sabah, Malaysia: A review. Asian Pac J Trop Biomed 2014, 10, 768-779, https://doi.org/10.12980/APJTB.4.2014C1144

62. Gyawali, D.; Vohra, R.; Orme-Johnson, D.; Ramaratnam, S.; Schneider, R.H. A systematic review and metaanalysis of Ayurvedic herbal preparations for hypercholesterolemia. Medicina (Kaunas) 2021, 57, 546, http://doi.org/10.3390/medicina57060546.

63. Preethi, L.; Ganamurali, N.; Dhanasekaran, D.; Sabarathinam, S. Therapeutic use of Guggulsterone in COVID-19 induced obesity (COVIBESITY) and significant role in immunomodulatory effect. Obes Med 2021, 24, 100346, https://doi.org/10.1016/j.obmed.2021.100346.

64. Koriem, K.M.M. A lipidomic concept in infectious diseases. Asian Pac J Trop Biomed 2017, 7, 265-274, https://doi.org/10.1016/j.apjtb.2016.12.010.

65. Zhu, S.S.; Liu, J.W.; Yan, Y.M.; Liu, Y.; Mao, Z.; Cheng, Y.X. Terpenoids from Resina Commiphora regulating lipid metabolism via activating PPARalpha and CPT1 expression. Org Lett 2020, 22, 3428-3432, http://doi.org/10.1021/acs.orglett.0c00898.

66. Orabi, S.H.; Al-Sabbagh, E.S.; Khalifa, H.K.; Mohamed, M.A.E.; Elhamouly, M.; Gad-Allah, S.M.; AbdelDaim, M.M.; Eldaim, M.A.A. Commiphora myrrha resin alcoholic extract ameliorates high fat diet induced obesity via regulation of UCP1 and adiponectin proteins expression in rats. Nutrients 2020, 12, 803, http://doi.org/10.3390/nu12030803.

67. Pessoa, R.F.; Duarte Figueiredo, I.A.; Dantas Ferreira, S.R.; Lima de Farias Cavalcanti Silva, A.R.; Marinho Paiva, R.L.; Cordeiro, L.V.; de Oliveira Lima, E.; Cabrera, S.P.; Sarmento Silva, T.M.; de Andrade Cavalcante, F. Investigation of ethnomedicinal use of Commiphora leptophloeos (Mart.) J. B. Gillett (Burseraceae) in treatment of diarrhea. $J$ Ethnopharmacol 2021, 268, 113564, http://doi.org/10.1016/j.jep.2020.113564.

68. Eid, R.A.A. Efficacy of Commiphora myrrh mouthwash on early wound healing after tooth extraction: A randomized controlled trial. Saudi Dent J 2021, 33, 44-54, http://doi.org/10.1016/j.sdentj.2019.11.011.

69. Faraji, A.; Aghdaki, M.; Hessami, K.; Hosseinkhani, A.; Roozmeh, S.; Asadi, N.; Vafaei, H.; Kasraeian, M.; Bagheri, R.; Bazrafshan, K.; Foroughinia, L. Episiotomy wound healing by Commiphora myrrha (Nees) Engl. and Boswellia carteri Birdw. in primiparous women: A randomized controlled trial. J Ethnopharmacol 2021, 264, 113396, http://doi.org/10.1016/j.jep.2020.113396.

70. Omer, S.A.; Adam, S.E.; Khalid, H.E. Effects on rats of Commiphora myrrha extract given by different routes of administration. Vet Hum Toxicol 1999, 41, 193-196.

71. Opdyke, D.L. Monographs on the fragrance of raw materials. Myrrh oil. Food Chem Toxicol 1976, 18, 649650 .

72. Omer, S.A.; Adam, S.E. Toxicity of Commiphora myrrha to goats. Vet Hum Toxicol 1999, 41, $299-301$.

73. Rao, R.M.; Khan, Z.A.; Shah, A.H. Toxicity studies in mice of Commiphora molmol oleo-gum-resin. $J$ Ethnopharmacol 2001, 76, 151-154, http://doi.org/10.1016/s0378-8741(01)00189-1.

74. Asad, M.; Asdaq, S.M.B.; Mohzari, Y.; Alrashed, A.; Alajami, H.N.; Aljohani, A.O.; Mushtawi, A.A.A.; Alajmi, A.N.; Alajmi, H.N.; Imran, M.; Orfali, R. Pharmacokinetic and pharmacodynamic interaction of Rosuvastatin calcium with guggulipid extract in rats. Saudi J Biol Sci 2021, 28, 3490-3496, http://doi.org/10.1016/j.sjbs.2021.03.015.

75. Lee, T.Y.; Lam, T.H. Myrrh is the putative allergen in bonesetter's herbs dermatitis. Contact Dermatitis 1993, 29, 279, http://doi.org/10.1111/j.1600-0536.1993.tb03571.x.

76. Lee, T.Y.; Lam, T.H. Allergic contact dermatitis due to a Chinese orthopaedic solution tieh ta yao gin. Contact Dermatitis 1993, 28, 89-90, http://doi.org/10.1111/j.1600-0536.1993.tb03348.x.

77. Al-Suwaidan, S.N.; Gad el Rab, M.O.; Al-Fakhiry, S.; Al Hoqail, I.A.; Al-Maziad, A.; Sherif, A.B. Allergic contact dermatitis from myrrh, a topical herbal medicine used to promote healing. Contact Dermatitis 2007, 39, 137, http://doi.org/10.1111/j.1600-0536.1998.tb05867.x.

78. Saha, J.C.; Savini, E.C.; Kasinathan, S. Ecbolic properties of Indian medicinal plants. Part I. Indian J Med Res 1961, 49, 130-151.

https://biointerfaceresearch.com/ 
79. Yin, X.J.; Liu, D.X.; Wang, H.C.; Zhou, Y. A study on the mutagenicity of 102 raw pharmaceuticals used in Chinese traditional medicine. Mutat Res 1991, 260, 73-82, https://doi.org/10.1016/0165-1218(91)90082-W.

80. Liu, D.X.; Yin, X.; Wang, H.; Zhou, Y.; Zhang, Y. . [Antimutagenicity screening of water extracts from 102 kinds of Chinese medicinal herbs.] Chung-kuo Chung Yao Tsa Chi Li 1990, 15, 617-622, PMID: 2268399.

81. Tian, H.; Gui, Y.; Wei, Y.; Shang, B.; Sun, J.; Ma, S.; You, W.; Jiang, S. Z-guggulsterone induces PD-L1 upregulation partly mediated by FXR, Akt and Erk1/2 signaling pathways in non-small cell lung cancer. Int Immunopharmacol 2021, 93, 107395, https://doi.org/10.1016/j.intimp.2021.107395,

82. Koriem, K.M.M. Protective effect of natural products and hormones in colon cancer using metabolome: A physiological overview. Asian Pac J Trop Biomed 2017, 7, 957-966, https://doi.org/10.1016/j.apjtb.2017.09.002.

83. Abdellatef, A.A.; Zhou, Y.; Yamada, A.; Elmekkawy, S.A.; Kohyama, A.; Yokoyama, S.; Meselhy, M.R.; Matsuya, Y.; Sakurai, H.; Hayakawa, Y. Synthetic E-guggulsterone derivative GSD-1 inhibits NF- $\kappa$ B signaling and suppresses the metastatic potential of breast cancer cells. Biomed Pharmacother 2021, 140, 111737, https://doi.org/10.1016/j.biopha.2021.111737.

84. Qureshi, S.; al-Harbi, M.M.; Ahmed, M.M.; Raza, M.; Giangreco, A.B.; Shah, A.H. . Evaluation of the genotoxic, cytotoxic, and antitumor properties of Commiphora molmol using normal and Ehrlich ascites carcinoma cell-bearing Swiss albino mice. Cancer Chemother Pharmacol 1993, 33, 130-138, https://doi.org/10.1007/BF00685330 